FIU Law Review

Spring 2011

\title{
Arizona's SB1070, Copycat Bills, and Constitutional Conundrums: Costly Collisions?
}

Imtiaz Hussain

Universidad Iberoamericana, Mexico City

Follow this and additional works at: https://ecollections.law.fiu.edu/lawreview

Part of the Other Law Commons

Online ISSN: 2643-7759

\section{Recommended Citation}

Imtiaz Hussain, Arizona's SB1070, Copycat Bills, and Constitutional Conundrums: Costly Collisions?, 6 FIU L. Rev. 201 (2011).

DOI: https://dx.doi.org/10.25148/lawrev.6.2.5

This Article is brought to you for free and open access by eCollections. It has been accepted for inclusion in FIU Law Review by an authorized editor of eCollections. For more information, please contact lisdavis@fiu.edu. 


\title{
Arizona's SB1070, Copycat Bills, and Constitutional Conundrums: Costly Collisions?
}

\author{
Imtiaz Hussain
}

\section{SB1070 PUZZLE}

Approved by a 17-13 vote in the Arizona Senate on February 15, 2010, and by a 35-21 vote in the Arizona House on April 13, 2010, Arizona's anti-immigration legislation, Senate Bill 1070 ("SB1070"), was signed by Republican Governor Janice K. Brewer on April 23, 2010, four days after a 17-11-2 Senate concurrence vote.

SB1070 permits law enforcement officers, on the basis of "reasonable suspicion" formed during a "lawful stop, detention or arrest," to apprehend any person who cannot supply one of four types of acceptable identification: a valid Arizona driver's license, non-operating Arizona driver's license, other federal, state, or municipal identification, or tribal identification. ${ }^{2}$

While first-time offenders are subject to imprisonment for up to twenty days and a one-hundred-dollar fine (plus court costs), ${ }^{3}$ repeat offenders may be imprisoned for up to thirty days. ${ }^{4}$ SB1070 prohibits: (a) police officers from neglecting "the enforcement of federal immigration laws," which require foreigners over fourteen years of age to register with the U.S. government within thirty days of entry and to

\footnotetext{
Professor of International Relations, Department of International Studies, Universidad Iberoamericana, Mexico City. This paper was presented at the LLEADS-sponsored law symposium (\#2) on immigration at Florida International University College of Law, Miami, FL, in February 2011. I appreciated the comments, well-knitted organization, and the meticulous subsequent editorial review.

1 S.B. 1070, 2010 Leg., 49th Sess. (Ariz. 2010).

ARIZ. REV. STAT. § 11-1051(B) (2011).

Id. $§ 13-1509(\mathrm{H})(2011)$.

4 Kristi Eaton, Arizona's Law Is the Most Extreme Anti-immigration Measure -- For Now, CAMPUS PROGRESS (May 26 , 2010), http://campusprogress.org/articles/arizonas_law_is_most_extreme_antiimmigration_measurefor_now; Alia Rau, Ginger Rough \& Yvonne Wingett, Arizona Immigration Law Costs and Savings, AzCENTRAL (July 11, 2010), http://www.azcentral.com/news/election/azelections/articles/2010/07/09/20100709arizonaimmigration-law-costs-to-state.html; see also Understanding SB1070, MESSING L. OFFICES (Nov. 2011), http://www.messinglawoffices.com/Understanding_sb_1070.aspx.
} 
carry certain immigration documents at all times, ${ }^{5}$ (b) recruitment of workers from a vehicle "block[ing] or imped[ing] the normal movement of traffic,", and (c) facilitating the "furtherance" of an illegal immigrant by transportation, "conceal[ing], harbor[ing] or shield[ing]" an undocumented immigrant, or inviting an undocumented immigrant to reside in the state, provided the accused "knows or recklessly disregards" the invitee's undocumented status. ' Another provision permits a $\$ 1,000$ misdemeanor fine for harboring undocumented immigrants. The misdemeanor fine is elevated to a felony if more than ten undocumented immigrants are involved. ${ }^{8}$

Considering that four hundred and sixty thousand of Arizona's two million Hispanic residents are illegal immigrants, SB1070 provoked charges of racial profiling, institutional racism, and apartheid (similar to South Africa's Pass Laws), and exposed constitutional conundrums and state-federal feuds. But SB1070 was popular: 71 percent of the Arizona population favored it, while 51 percent of Americans favored similar legislation across the United States. ${ }^{10}$ Nevertheless, on July 28, 2010, District Court Judge Susan Bolton issued an injunction concluding SB1070 would cause the United States "irreparable harm." ${ }^{11}$ Thereafter, on August 10, 2011, in the aftermath of an initial (unsuccessful) appeal, Arizona Governor Brewer filed a petition for writ of certiorari in the United States Supreme Court rather than pursue a second appeal to the Ninth Circuit.

With SB1070 copycats proliferating, spiking all kinds of collisions and raising solution costs, ${ }^{13}$ no fair settlement seems likely unless it reflects each of four powerful forces at play: the state of the economy

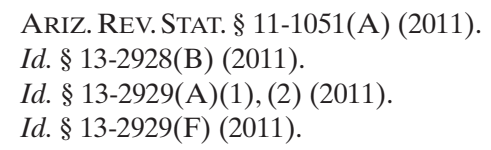

9 Nathan Thornburgh, Border Crackdowns and the Battle for Arizona, Time (June 14, 2010), http://www.time.com/time/magazine/article/0,9171,1993875,00.html.

10 City Councils Eye Boycotts, N.Y. DAILY NEWs (Apr. 30, 2010), http://articles.nydailynews.com//2010-04-30/news/27063159_1_arizona-law-illegal-immigrantsboycotts; Ethan Sacks, Battle Over Arizona's SB 1070: Oklahoma Eyes Similar Immigration Law, N.Y. DAILY NEWS (Apr. 30, 2010), http://articles.nydailynews.com/2010-0430/news/27063159_1_arizona-law-illegal-immigrants-boycotts.

11 United States v. Arizona, 641 F.3d 339 (9th Cir. 2011).

12 Petition for Writ of Certiorari, Arizona v. United States, No. 11-182, 2011 WL 3562633, at *1 (filed Aug. 10, 2011), cert. granted, 132 S. Ct. 845 (2011).

13 For example, the Mexican National Confederation of Popular Organizations (CNOP) counted 1,100 U.S. hate groups in May 2011 -- a sharp increase from the 840 counted in 2008. Edmundo Ramirez, CNOP's Department of Migrant Affairs chief, attributes this increase to "a negative stigma against Mexicans" due to "the Arizona Law (SB1070), the fear of immigrants, the economic crisis, and the United States' high unemployment rate." U.S. Hate Crimes Up in Obama's Tenure, DAILY NEWS (Mexico City), June 27, 2011, at 1. 
(recession); politics (electoral calculations); the law (constitutional tussles); and demographic changes (elevating Hispanic over white population groups). ${ }^{14}$ In the meantime, because a lot of water will have flown, bridge-building is imperative to avoid the flood. ${ }^{15}$ To understand what is at stake, this article, in the following three subsections, elaborates on the roots, proliferation, and constitutional consequences of SB1070-type legislation, and then appraises the costs, draws conclusions, and projects the implications of SB1070 and similar legislations.

\section{A. SB1070's Roots}

Translating anti-immigration sentiment into legislation has been historically significant. The most significant efforts include the 1882 Chinese Exclusion Act, ${ }^{16}$ and the 1924 Immigration Act, ${ }^{17}$ both of which targeted Asians, particularly those of Japanese descent. ${ }^{18}$ The present anti-immigration uproar can arguably be traced to President Lyndon B. Johnson's Immigration Act of $1965,{ }^{19}$ which replaced quotas for a preference-based system, but more pertinently, pitted supporters of "successful Euro-American culture" against the growth of nonwhite groups. ${ }^{20}$ Among the leaders of the reform movement was John Tanton, who founded the Federation of American Immigration Reform (FAIR) in 1979 and, together with Jared Taylor and Sam Francis, gave birth to the League for European-American Defense, Education and Research (LEADER). ${ }^{21}$

The founders' attitudes, opinions, and preferences were given teeth by a second generation of FAIR leaders: Kris Kobach, Michael Hethmon, Dan Stein, Rick Oltman, Donald Collins, and Garrett Hardin, among others. Kobach, for instance, was a senior FAIR counsel before being elected as the Kansas Secretary of State in 2010, while

14 The Legal Challenges and Economic Realities of Arizona's SB1070, IMMIGR. POL'Y CENTER (May. 11, 2010), http://www.immigrationpolicy.org/just-facts/legal-challenges-andeconomic-realities-arizonas-sb-1070-resource-page.

15 Jorge Castañeda, Gratitude for Arizona: Its Aggressive Law Could Spur Action, NEWSWEEK, May 24 \& 31, 2010, at 20.

16 Chinese Exclusion Act, ch. 126, 22 Stat. 58 (1882) (repealed 1943).

17 Immigration Act of 1924, ch.190, § 11(d), 43 Stat. 153 (1924) (repealed 1952).

18 The 1790 Naturalization Act limited citizenship to "free white persons," thus excluding the Issei (immigrant generation from Japan). Naturalization Act of 1790, ch. 3, 1 Stat. 103.

19 Immigration Act of 1965, Pub. L. No. 89-236, 79 Stat. 911. This legislation ended the forty-year ban on Japanese and other Asian immigrants.

20 The Organization: FAIR's Nativist History, S. Poverty L. CENTER (Jan. 20, 2011), http://www.splcenter.org/get-informed/publications/when-mr-kobach-comes-to-town/theorganization-fairs-nativist-history.

21 Id. But see Adrian H. Krieg, SPLC: America's Self-Appointed Thought Police, FED. OBSERVER (Jan. 31, 2012), http://www.federalobserver.com/archive.php?aid=1151. 
Hethmon became the General Counsel of the Immigration Reform Law Institute (IRLI), the legal arm of FAIR. ${ }^{22}$ Kobach authored SB1070 and similar legislation elsewhere, ${ }^{23}$ and simultaneously defended the enactments against the U.S. government, spiking local government costs (largely to cover legal fees, which Kobach pocketed). Hethman's most emphatic SB1070 copycat bill was proposed by Republican State Representative Stephen Sandstrom in Utah. ${ }^{24}$ Whereas FAIR's early leaders focused reform efforts primarily against AfricanAmericans, Jews, and Catholics, the new FAIR generation shifted its attention to Hispanics. Table 1 identifies these leaders and their relevant attitudes.

Table 1: Fair to be F.A.I.R.?

\begin{tabular}{|c|c|c|}
\hline Selected Leaders: & Target-groups: & How viewed: \\
\hline $\begin{array}{c}\text { Kris Kobach: } \\
\text { *Senior FAIR Counsel, } \\
\text { but now Kansas Secretary } \\
\text { of State } \\
\text { *Harvard thesis advisor: } \\
\text { Samuel P. Huntington of } \\
\text { civilization clash fame } \\
\text { *Department of Justice } \\
\text { mentor: Attorney General } \\
\text { John Ashcroft, 2001-2005 } \\
\text { *Author of SB1070 and } \\
\text { several other similar } \\
\text { ordinances (in Hazelton, } \\
\text { PA, for example) }\end{array}$ & Afro-Americans: & $\begin{array}{c}\text { *Taylor: "when blacks are } \\
\text { left entirely to their own } \\
\text { devices, Western } \\
\text { civilization ... disappears" } \\
\text { *Oltman: They are a } \\
\text { "retrograde species of } \\
\text { humanity" }\end{array}$ \\
\hline $\begin{array}{c}\text { John Tanton: } \\
\text { *Founder of FAIR (in } \\
1979 \text { ) } \\
\text { *Co-founder of LEADER }\end{array}$ & Catholics: & $\begin{array}{l}\text { *Collins: They sold the } \\
\text { United States on } \\
\text { immigration } \\
\text { "in exchange for more } \\
\text { temporal power and } \\
\text { glory" }\end{array}$ \\
\hline Jarred Taylor: & & $\begin{array}{c}\text { *Tanton's mentor, John } \\
\text { Trevor, Sr. (who co- }\end{array}$ \\
\hline $\begin{array}{l}22 \text { Center for Ne } \\
\text { http://www.newcomm.org/pdf/C } \\
23 \text { For example, in Hazlet } \\
\text { 2006), Farmers Branch, Texas ( } \\
24 \text { Republican Extremists } \\
\text { SPEAKING NEWS (Dec. } 23\end{array}$ & \multicolumn{2}{|c|}{$\begin{array}{l}\text { Community, IMMIGR. REFORM L. INST., } \\
\text { IRL.pdf (last visited Feb. 29, 2012). } \\
\text { Pennsylvania (July 13, 2006), Valley Park, Missouri (July 17, } \\
\text { 13, 2006), and Fremont, Nebraska (July 29, 2008). } \\
\text { h Utah Towards Anti-Immigrant Legislation, HISPANICALLY } \\
\text { 2010), http://www.hispanicallyspeakingnews.com/notitas-de- } \\
\text { ts-push-utah-towards-anti-immigrant-legislation/3760/. }\end{array}$} \\
\hline
\end{tabular}




\begin{tabular}{|c|c|c|}
\hline *Co-founder of LEADER: & Jews: & $\begin{array}{c}\text { authored the } 1924 \\
\text { Immigration Act): spoke } \\
\text { of a } \\
\text { "diabolic Jewish control } \\
\text { of America" }\end{array}$ \\
\hline $\begin{array}{c}\text { Sam Francis: } \\
\text { * Co-founder of LEADER }\end{array}$ & Latinos: & $\begin{array}{l}\text { *Tanton: U.S. faces a } \\
\text { "Latin onslaught"; } \\
\text { Latinos known for } \\
\text { "defecating and creating } \\
\text { garbage and looking for } \\
\text { jobs"; they have "low } \\
\text { educability" and a } \\
\text { "tradition of mordida" }\end{array}$ \\
\hline $\begin{array}{c}\text { Dan Stein: } \\
\text { *Current FAIR president } \\
\text { David Collins: } \\
\text { *FAIR leader } \\
\text { Rick Oltman: } \\
\text { *FAIR leader }\end{array}$ & Mexicans: & $\begin{array}{l}\text { *Francis: They carry a } \\
\text { "political bludgeon } \\
\text { against the United States" }\end{array}$ \\
\hline $\begin{array}{c}\text { Michael Hethman: } \\
\text { *General Counsel,IRLI, } \\
\text { legal arm of FAIR } \\
\text { *Wrote Utah's SB1070 } \\
\text { copycat bill }\end{array}$ & Third World: & $\begin{array}{l}\text { *Hardin: They are } \\
\text { "breeders", "diluting what } \\
\text { we and who we are" }\end{array}$ \\
\hline
\end{tabular}

Notwithstanding FAIR's classification as a hate group by the Southern Poverty Law Center (SPLC), ${ }^{25}$ among others, ${ }^{26}$ its extremist views were crystallized into the State Legislators for Legal Immigration (SLLI), a conservative legislative group opposed to the Fourteenth Amendment and opposed by the American Civil Liberties Union $(\mathrm{ACLU}){ }^{27}$

25 Federation for American Immigration Reform, S. POVERTY L. CENTER, http://www.splcenter.org/get-informed/intelligence-files/groups/federation-for-americanimmigration-reform-fair (last visited Feb. 29, 2012).

26 See, e.g., Legislators Work with Anti-Immigrant Hate Group to Gut 14th Amendment, Hous. PEACE COUNCIL (Jan. 8, 2011), http://www.houstonpeacecouncil.com/legislators-workwith-anti-immigrant-hate-group-to-gult-14th-amendment/.

27 Jill Garvey, State Legislators Unveil Plan to Attack the 14th Amendment, FACE PROTESTS (Jan. 6, 2011), http://imagine2050.newcomm.org/2011/01/06/state-legislators-unveil-plan-toattack-the-14th-amendment-face-protests. 


\section{B. SB1070's Proliferation}

Arizona's anti-immigration legislation was not the first of its kind: ${ }^{28}$ In 2007, Oklahoma's Taxpayer and Citizen Protection Act, introduced by Republican Representative Randy Terrill, made it illegal to transport or employ undocumented immigrants. ${ }^{29}$ Nevertheless, SB1070 rippled across the United States, beginning in Oklahoma, where Terrill introduced a second anti-immigration bill, the "Arizona Plus" bill, which sought to seize vehicles and property used to harbor or transport undocumented immigrants.

By early 2011, at least fourteen states had introduced copycat SB1070 bills: Florida, Georgia, Illinois, Indiana, Kentucky, Michigan, Minneapolis, Mississippi, Nebraska, Pennsylvania, Rhode Island, South Carolina, Texas, and Utah. ${ }^{31}$ Eight others were actively considering passage of anti-immigration legislation: Arkansas, Colorado, Idaho, Maryland, North Carolina, Ohio, and Tennessee. ${ }^{32}$ Appendix 1 lists the wide variety of anti-immigrant measures considered: preventing public school attendance (Georgia, Iowa, North Carolina), prohibiting issuance of a driver's license (New Mexico), utilizing Everification to halt remittance outflows (Colorado), and seizing vehicles driven by undocumented immigrants (Oklahoma, South Carolina, Utah) or if used to harbor and transport the undocumented persons (Oklahoma, South Carolina), and so forth. Attempts to modify the Fourteenth Amendment, which ensures automatic citizenship for persons born on U.S. soil, are also underway in Georgia and Pennsylvania.

Table 2 narrows the Appendix 1 list, pointing out where other anti-immigration battles are, or will be, raging. SB1070 copycat legisla-

28 In 2007 and 2008, two hundred immigration-related bills were passed in forty states; from 2000 to 2009, one hundred and seven U.S. towns, cities, or counties passed anti-immigration laws. See Seth F. Wessler, Report: White Anxiety Fuels Anti-Immigrant Laws, COLOR LINES (Nov. 12, 2010), http://colorlines.com/archives/2010/11/in_the_shadows_of_arizonas.html; Daniel B. Wood, After Arizona, Why Are 10 States Considering Immigration Bills?, CHRISTIAN SCI. MONITOR (May 10, 2010), http://www.csmonitor.com/USA/Society/2010/0510/After-Arizonawhy-are-10-states-considering-immigration-bills.

29 H.B. 1804, 51st Leg., 1st Sess. (Okla. 2007); OKLA. STAT. tit. 25, § 1313(A) (2011).

30 Julia Preston, Political Battle on Illegal Immigration Shifts to States, N.Y. TIMES (Dec. 31, 2010), http://www.nytimes.com/2011/01/01/us/01immig.html.

31 Lois Romano, States Inspired by Arizona Illegal-Immigration Law Face Tough Fiscal Realities, WASH. POST (Jan. 29, 2011), http://www.washingtonpost.com/WPdyn/content/article/2011/01/28/ AR2011012804042.html.

32 S. F. Wessler, 15 States Looking at SB1070 Copycat Bills - Despite Unconstitutionality, Racial Profiling, ALTERNET (Mar. 3, 2011), http://www.alternet.org/newsandviews/article/511281/ 15_states_looking_at_SB_1070_copycat_bills_-_despite_unconstitutionality_racial_profiling/.

33 Such initiatives have been led by State Representative Daryl Metcalfe in Pennsylvania and by Representative Berman in Texas under HB292. 
tion has proliferated in number and degree: Alabama's proposal threatens to match or even exceed the severity of Arizona's, ${ }^{34}$ while, at the other end, Utah hopes to blend punitive with reformative measures. ${ }^{35}$ Other states fall in between.

\section{Table 2: SB1070 Copycats: "Attrition Through Enforcement"}

\begin{tabular}{|c|c|c|}
\hline States: & Pro-Legislation/Action: & Anti-Legislation/action: \\
\hline Alabama: & $\begin{array}{c}\text { *June 8, 2011: Governor } \\
\text { Robert Bentley (R) signs } \\
\text { bill; } \\
\text { *To be implemented } \\
\text { September 1,2011 }\end{array}$ & $\begin{array}{l}\text { *Mary Bauer (SPLC) calls } \\
\text { it "mean spirited, racist, } \\
\text { unconstitutional, and ... } \\
\text { costly" }\end{array}$ \\
\hline $\begin{array}{l}\text { Carolinas: } \\
\text { *North } \\
\text { *South }\end{array}$ & $\begin{array}{l}\text { *Safe Students Act } \\
(\text { HB744): Principals } \\
\text { required to ask parents of } \\
\text { child's citizenship and } \\
\text { immigration status, as well } \\
\text { as submit birth certificate } \\
\text { *Copycat SB1070 bill } \\
\text { passed the House } 69-43 \text {, } \\
\text { and expected to be signed } \\
\text { by Governor Nikki Halley }\end{array}$ & $\begin{array}{l}\text { * Runs afoul of federal law: } \\
1982 \text { U.S. Supreme Court } \\
\text { ruled that any child born in } \\
\text { the United States has right } \\
\text { to education }\end{array}$ \\
\hline Connecticut: & $\begin{array}{l}\text { *May 26, 2011: In-state } \\
\text { tuition permitted for } \\
\text { undocumented immigrants: } \\
\text { They should not pay for } \\
\text { their parents' error } \\
\text { (Senate voted 21-14) } \\
\text { *Governor Daniel P. } \\
\text { Malloy signed it }\end{array}$ & \\
\hline
\end{tabular}

34 Julianne Hing, Alabama House Passes SB1070-Inspired Bill, MARIOWIRE (Apr. 8, 2011), http://www.mariowire.com/2011/04/08/alabama-passes-sb-1070-bill/.

35 Tom Anderson, Utah's "SB1070 Light", Socialist APPEAL (Nov. 22, 2010), http://www.socialistappeal.org/analysis/immigration/820-utahs-sb1070-light-.

36 Seth F. Wessler, Arizona SB 1070 Copycats Fall Flat in Most Legislatures, COLOR LINES (Mar. 31, 2011),

http://colorlines.com/archives/2011/03/arizona_sb_1070_copycats_fall_flat_in_most_state_legislat ures.html. 


\begin{tabular}{|c|c|c|}
\hline Georgia: & $\begin{array}{l}\text { *HB87, a SB1070 copycat, } \\
\text { supported by Center for } \\
\text { Immigration Studies }\end{array}$ & $\begin{array}{c}\text { *Threatens } 425,000 \\
\text { undocumented immigrants, } \\
\text { of whom } 100,000 \text { (mostly } \\
\text { Mexicans) fled during } 2010\end{array}$ \\
\hline Texas: & $\begin{array}{l}\text { *June 16, 2011: SB9 } \\
\text { approved 19-12: Halts state } \\
\text { aid to local government } \\
\text { that do not allow local } \\
\text { officers to inquire about } \\
\text { immigration; officers } \\
\text { permitted (not required) to } \\
\text { ask for citizenship status) }\end{array}$ & $\begin{array}{l}\text { *Hispanics decry it for } \\
\text { discrimination }\end{array}$ \\
\hline Utah: & $\begin{array}{l}\text { *3 bills seek supported by } \\
\text { Governor Gary R. Herbert } \\
(\mathrm{R}) \text { : tougher enforcement; } \\
\text { GWP to meet local needs; } \\
\text { and fines and work permits } \\
\text { for undocumented } \\
\text { immigrants already in Utah } \\
\text { *Makes it harder to rent } \\
\text { and get driver's license; law } \\
\text { enforcement officials get } \\
\text { more leeway }\end{array}$ & $\begin{array}{c}\text { *Needs Washington } \\
\text { "waiver" to give amnesty } \\
\text { *GWP needs federal } \\
\text { government cooperation } \\
\text { *President William Gheen } \\
\text { of Americans for Legal } \\
\text { Immigration calls GWP } \\
\text { "amnesty" } \\
\text { *Opposed by ACLU and } \\
\text { National Immigration Law } \\
\text { Center }\end{array}$ \\
\hline
\end{tabular}

Alabama's Governor, Robert Bentley, signed what he called a "tough illegal immigration law" on June 8,2011 (the law provides for implementation on September 1, 2011). ${ }^{37} \quad$ SPLC's Mary Bauer describes the legislation as "mean spirited, racist, unconstitutional, and . . . costly.", Georgia's SB1070 copycat bill, HB87, scheduled to be implemented even sooner, led to a massive out-migration of its 425,000 undocumented immigrants, of whom 100,000, mostly Mexicans, left in 2010. ${ }^{40}$ In the meantime, Texas's "sanctuary city" bill, SB9, which

37 Alabama Governor Signs Tough New Immigration Law, CNN (June 9, 2011), http://articles.cnn.com/2011-06-09/us/alabama.immigration_1_illegal-immigration-immigrationlaw-immigration-status?_s=PM:US.

38 Id.

39 Jeremy Redmon, Georgia Lawmakers Pass Illegal Immigration Crackdown, ATLANTA J. CONST. (Apr. 14, 2011), http://www.ajc.com/news/georgia-lawmakers-pass-illegal-909988.html.

40 J. Redmon \& Mario Guevara, Immigrants Leaving Georgia Behind Them: They're Fleeing Before a Tough Immigration Law Takes Effect on July 1, DAILY NEWs (Mexico City), June 9, 2011 , at 5 .

41 Julian Aguilar, Sanctuary Cities Bill Clears Texas Senate, TEX. TrIB. (June 15, 2011), http:/www.texastribune.org/texas-legislature/82nd-legislative-session/sanctuary-cities-bill-clearstexas-senate/. 
Hispanics decry as being discriminatory, passed the Senate 19-12 on June 16, 2011, and also provides for early implementation. ${ }^{42}$

Utah, on the other hand, is attempting to do what the United States has been unable to do at the federal level: reform immigration policy. Utah Governor Gary R. Herbert has backed the passage of three laws simultaneously seeking tougher enforcement: specifically, a guest-worker program (GWP) to meet labor needs, ${ }^{43}$ the imposition of fines for hiring undocumented immigrants, and the issuance of work permits for undocumented immigrants already in the state. ${ }^{44}$ As with SB1070, Utah's legislation authorizes law enforcement officers to take immigration matters into their own hands by asking for identification. However, unlike SB1070, employer sanctions are tighter and an undocumented immigrant's ability to rent an apartment or obtain a driver's license is much more restricted. This is also the case with Alabama's anti-immigration law. ${ }^{45}$ Yet, the reform-minded elements in Utah's legislation invite perhaps even more legal contestation. ${ }^{46}$ For example, the adoption of a GWP necessitates federal-level cooperation, ${ }^{47}$ while legalizing undocumented immigrants already settled in Utah also requires a Washington "waiver."

Other contentious issues include generalizing Mississippi's Everification method at the federal level and delineating the kind of tuition payment appropriate for undocumented children. By adopting Mississippi's E-verification method, ${ }^{49}$ the U.S. Customs and Immigration Services, under the U.S. Department of Homeland Security, opened one possibility that other states might replicate. ${ }^{50}$ The Ala-

42 David Montgomery, Texas Passes a Tough Immigration Measure: State Gov't to Halt Aid to Cities that Prohibit Asking Migratory Status, DAILY NeWs (Mexico City), June 17, 2011, at 4.

43 William Gheen, President of the conservative group Americans for Legal Immigration, calls the GWP an "amnesty."

44 Alan Gomez, Utah Immigration Plan Could Stir Legal Storm, USA TODAY (Aug. 3, 2011), http://www.usatoday.com/news/nation/2011-03-08-utah08_ST_N.htm.

45 Ben Montgomery, Ala. Law Could Affect Outreach Programs: The New Immigration Code Will Also Hit Property Renters in State, DAILY NeWs (Mexico City), June 27, 2011, at 4.

46 Tamar Jacoby, Reform: The Utah Way, DAILY News (Mexico City), March 29, 2011; Josh Loftin, Utah's Anti-immigration Law is Stuck: At Least Some Portions Would be Unconstitutional, DAILY NEWS (Mexico City), May 12, 2011, at 4.

47 State Rep. Ellis Black Issues Legislative Update, VALdosta DAILY Times (Apr. 19, 2011), http://www.valdostadailytimes.com/x1812407129/State-Rep-Ellis-Black-issues-legislativeupdate.

48 Devin Dwyer, Utah Approves Guest Worker Program for Illegal Immigrants, ABC WORLD NEWS (Mar. 7, 2011), http://abcnews.go.com/Politics/utah-approves-guest-workerprogram-illegal-immigrant/story?id=13071198.

49 Mississippi: Mississippi Employment Protection Act Signed Into Law, OGLETREE DEAKINS (Apr. 4, 2008), http://www.ogletreedeakins.com/publications/2008-04-04/mississippimississippi-employment-protection-act-signed-law.

50 E-verify is administered by the U.S. Department of Homeland Security and the Social Security Administration, but was created under the 1996 Illegal Immigration Reform and Immi- 
bama bill, which originated as HB63, ${ }^{51}$ quickly followed suit, but Angélica Salas, of the Coalition for Humane Immigration Rights Los Angeles, describes this method as creating a "massive bureaucratic bottleneck for small businesses." 52 She argues E-verify "would immediately signify massive red-tape for small businesses, economic setback for industries desperately trying to get back on their feet, and prove disastrous for millions of hard-working immigrant employees and their U.S.-born loved ones.", In short, "we need mandatory E-Verify," she cynically posited, "like we need endodontic therapy." Mexico and thirteen other Latin-American countries also expressed their dissatisfaction.

Some states require undocumented immigrants to pay in-state tuition: California, ${ }^{56}$ Connecticut, Maryland, New Mexico, Texas, and eight other states, are among them. ${ }^{57}$ Out-of-state tuition payment is a requirement, or in the process of becoming one, in Arizona, Colorado, Georgia, and Indiana. ${ }^{58}$ In addition, undocumented children may be questioned by school authorities about their citizenship or immigration status and are obligated to submit birth certificates. ${ }^{59}$ Undocumented children may also be penalized for being illegal, as a movement gathering storm in South Carolina posits. ${ }^{60}$ Tuition battle lines

grant Responsibility Act. Marc R. Rosenblum, E-verify: Strengths, Weaknesses, and Proposals for Reform, MPI InSIGHT (Feb. 2011), http://www.migrationpolicy.org/pubs/E-Verify-Insight.pdf.

51 Anti Illegal Immigration Laws, Documents \& ReS. FOR SMALl BuS. \& PROF'Ls, http://www.docstoc.com/docs/66836738/Anti-Illegal-Immigration-Laws (last visited Feb. 12, 2012); BRENNAN CENTER JUST., http://brennan.3cdn.net/3bed173c744ace8228_ejm6bnd7e.pdf (last updated June 2, 2011).

52 Businesses with less than twenty-five employees would have to contact the Department of Homeland Security for E-verification. See Adrián Jiménez, Alabama Cracking Down on Illegals: Mexico Speaks Out Against New Law, Offers Support, DAILY News (Mexico City), June 10, 2011, at 1; Montgomery, supra note 45.

53 Wendell Marsh, Bill Would Make Immigration E-Verify Mandatory, MARIOWIRE IMMIGR. (June 15, 2011), http://www.mariowire.com/politics/2011/06/15/bill-make-immigration-everify-mandatory/.

54 Bill Would Make Immigration E-Verify Mandatory, REUTERS (June 14, 2011), http://www.reuters.com/article/2011/06/14/us-immigration-e-verify-idUSTRE75D6HQ20110614.

55 Jiménez, supra note 52.

56 Larry Gordon and David Savage, Ruling on Calif. Tuition Rates Might Set the Path: Illegal Immigrants Keep In-state Tuition, DAILY NEWS (Mexico City), June 8, 2011, at 4.

57 Daniela Altimari, In-State Tuition Bill for Illegals Approved: Connecticut's Senate Gave the Legislative Approval; the Vote Was 21-14, DAILY NEWS (Mexico City), May 27, 2011, at 5.

58 Undocumented Student Tuition: State Action, NAT'L CONF. ST. LEGISLATURES (Oct. 2011), http://www.ncsl.org/issues-research/education/undocumented-student-tuition-stateaction.aspx.

59 Jane Stancill, Immigration Bill Stirs Opposition: Principals Would Have to Ask for Citizenship Info, DAILY NEWS (Mexico City), June 2, 2011, at 4.

60 States Stance on Immigration is Polarizing: They're Creating Their own Tuition Rules for Illegals, DAILY NEWS (Mexico City), May 20,2011, at 4. 
emanate from the 1982 U.S. Supreme Court ruling in Plyler v. Do ${ }^{61}$ that any child born in the United States has the right to an education. In the absence of comprehensive federal-level education planning, states are taking matters into their own hands and permitting antiimmigration sentiments to determine education policy. ${ }^{63}$ If not prompted by SB1070, clearly opening a Pandora's box of punitive measures pushes immigrant-bashing into unchartered territory.

Needless to say, these dynamics have taken on a political coloring. Immigration has become a top issue for 2012 gubernatorial election candidates. In Georgia, where at least a half-dozen anti-immigrant bills are pending in the state's two houses, both the Democrat and Republican governor nominees, Roy Barnes and Nathan Deal, favored SB1070-type legislation. ${ }^{64}$ By and large, Democrat governors have distanced themselves from SB1070 copycats. ${ }^{65}$ Additionally, many Republicans, who have been most stridently behind similar legislation, are thinking twice. ${ }^{66}$ Florida's former Governor, Jeb Bush, is worried about how the inevitable Hispanic swing-vote may hurt Republicans, ${ }^{67}$ while Somos Republicans, a group primarily comprised of Cubans in Florida, opposes such legislation. ${ }^{68}$ Florida Governor Rick Scott stands closer to imposing SB1070-type controls. ${ }^{69}$ Farm bureaus in Georgia, businesses in Texas and Utah, and law enforcement officers in Utah prefer SB1070 modifications. ${ }^{70}$ Although Arizona's Sena-

61 Plyler v. Doe, 457 U.S. 202 (1982).

62 Edwin S. Rubinstein, The Burden of Plyler v. Doe, Soc. CONT. Press (May 1, 2010), http://www.thesocialcontract.com/articles/plyler-v-doe.html.

$63 I d$.

64 Barnes Trip to Mexico Proclaimed Mexican Workers Good for Georgia, ATLANTA J. CONST. (Oct. 12, 2010), http:/www.politicalfact.com/georgia/statements/2010/oct/18/nathan$\mathrm{deal} /$ barnes-mexico-trip-sparks-new-round-attacks/.

65 A. Elena Lacayo, One Year Later: A Look at SB1070 and Copycat Legislation, NAT'L COUNCIL OF LA RAZA, http://nnaac.org/wp-content/uploads/2011/08/10-yearslater_Look_at_SB1070.pdf (last visited Feb.29,2012).

66 SB1070's Copycats See Trouble Now: Interested States Run Into Problems with Own Versions, ARIZ. DAILY STAR (Jan. 29, http://azstarnet.com/news/local/border/article_e50bae95_abbf-5fla-b7a0-6973f43261a5.html.

67 Jeb Bush Leads GOP Effort to Swing Hispanic Voters, CBS (Jan. 13, 2011), http://miamicbslocal.com/2011/01/13/jeb-bush-leads-gop-effort-to-swing-hispanic-voters/.

68 Bob Quasius, Somos Republicans and the Compact With America - A Powerful Remedy for the Anti-Immigrant Plague, LONG IsLAND WINS (Jan. 27, 2011), http://longislandwins.com/index.php/features/details/somos_republicans_and_the_compact_with _america_a_powerful_remedy_for_the_an/.

69 Luke Johnson, Rick Scott Endorses Arizona Immigration Law for Florida, AM. INDEP. (Dec. 7, 2010), http://www.americanindependent.com/160386/rick-scott-endorses-arizonaimmigration-law-for-florida.

70 A Year Later, States Draw Back From SB1070 Legislation, New AM. Media (July 29, 2011), http://newamericamedia.org/2011/07/a-year-on-states-draw-back-from-sb-1070-

legislation.php. 
tor Russell Pearce ascribes his SB1070 position to his church learning, other churches, including Utah Mormons, oppose such bills."

Social groups funnel individual sentiments toward legislative outcomes, and it seems the more there is coordination between these groups (as opposed to how many of them there are), the more successful their efforts. ${ }^{72}$ A September 2008 Progressive States Network (PSN) Report, "The Anti-Immigrant Movement that Failed," helps illustrate where the various states stand. Published almost two years before the SB1070 storm, the report places state immigration policies into sequential attitudinal categories: punitive (eight states), somewhat punitive (six), mixed (seven), somewhat integrative (10), integrative (seven), and inactive (thirteen).

Table 3 reproduces this list, while Table 4 explains how the antiimmigrant sentiment of a minority of states carries far larger consequences: states in the "punitive" and "somewhat punitive" categories accounted for 52.8 million of the U.S. population, far below the "somewhat integrative" (56.3 million people), "integrative" (88.9 million people), and "inactive" (64 million people) states. Of the "punitive" states, Arizona has the highest undocumented immigrant to total state population ratio (8.1 percent), while Utah has the second highest ratio at only 2.7 percent. Utah's figure is also higher than the highest undocumented immigrant ratio for "somewhat punitive" states: Rhode Island's ratio is 2.6 percent. We clearly see the large countrywide consequences of a tyranny of minority, small-group attitudes plaguing the United States at the start of the twenty-first century, just as a similar climate overwhelmed the country at the end of the nineteenth century (Chinese exclusion) and beginning of the twentieth century (Asian exclusion): policies may change, attitudes apparently do not.

71 Victoria M. Defrancesco Soto, Strange Bedfellows in Arizona's Recall of Russell Pearce, DRVMDS (July 28, 2011), http://drvmds.com/2011/07/strange-bedfellows-inArizona \%E2\%80\%99s-recall-of-russell-pearce/.

72 See, e.g., Lacayo, supra note 65.

73 The Anti-Immigration Movement That Failed: Positive Integration Policies by State Governments Still Far Outweigh Punitive Policies Aimed at New Immigrants, PROGRESSIVE STATES NETWORK (Sept. 2008), http://www.progressivestates.org/content/903/anti-immigrantmovement.that-failed.

74 Id. 
Table 3: Undocumented Immigration: A State-wide Breakdown

\begin{tabular}{|c|c|c|c|c|}
\hline States: & $\begin{array}{c}\text { Immigration } \\
\text { Policy } \\
\text { Stands: }\end{array}$ & $\begin{array}{c}\text { State } \\
\text { population } \\
(\mathbf{2 0 0 5 )}\end{array}$ & $\begin{array}{c}\text { Undocumented } \\
\text { Immigrants } \\
\text { (2005) }\end{array}$ & $\begin{array}{c}\text { Undocumented } \\
\text { Immigrants as \% } \\
\text { of Population }\end{array}$ \\
\hline Alabama: & Inactive & $4.6 \mathrm{~m}$ & 27,500 & .5 \\
\hline Alaska: & Inactive & 670,053 & 5,000 & .7 \\
\hline Delaware: & Inactive & 853,476 & 27,500 & 3.2 \\
\hline Florida: & Inactive & $18 \mathrm{~m}$ & 850,000 & 4.7 \\
\hline Kentucky: & Inactive & $4.2 \mathrm{~m}$ & 27,500 & .6 \\
\hline Montana: & Inactive & 944,632 & 5,000 & .5 \\
\hline Nevada: & Inactive & $2.5 \mathrm{~m}$ & 125,000 & .5 \\
\hline New Hampshire: & Inactive & $1.3 \mathrm{~m}$ & 5,000 & .4 \\
\hline North Dakota: & Inactive & 635,867 & 5,000 & .7 \\
\hline Ohio: & Inactive & 11.5 & 125,000 & 1.0 \\
\hline Pennsylvania: & Inactive & 12.5 & 125,000 & 1.0 \\
\hline South Dakota: & Inactive & 781,919 & 5,000 & .6 \\
\hline Wisconsin: & Inactive & $5.6 \mathrm{~m}$ & 125,000 & 2.2 \\
\hline California: & Integrative & $36.5 \mathrm{~m}$ & $2.4 \mathrm{~m}$ & 6.6 \\
\hline Illinois: & Integrative & $12.8 \mathrm{~m}$ & 400,000 & 3.1 \\
\hline Maryland: & Integrative & $5.6 \mathrm{~m}$ & 225,000 & 4.0 \\
\hline Massachusetts: & Integrative & $6.4 \mathrm{~m}$ & 225,000 & 3.5 \\
\hline New Mexico: & Integrative & $1.9 \mathrm{~m}$ & 70,000 & 3.6 \\
\hline New York: & Integrative & $19.3 \mathrm{~m}$ & 650,000 & 3.4 \\
\hline Washington: & Integrative & $6.4 \mathrm{~m}$ & 225,000 & 3.5 \\
\hline Connecticut: & $\begin{array}{l}\text { Somewhat } \\
\text { Integrative }\end{array}$ & $3.5 \mathrm{~m}$ & 70,000 & 2.0 \\
\hline District of Columbia: & $\begin{array}{l}\text { Somewhat } \\
\text { Integrative }\end{array}$ & 581,530 & 27,500 & 4.7 \\
\hline Hawaii: & $\begin{array}{l}\text { Somewhat } \\
\text { Integrative }\end{array}$ & $1.3 \mathrm{~m}$ & 27,500 & 2.1 \\
\hline Iowa: & $\begin{array}{l}\text { Somewhat } \\
\text { Integrative }\end{array}$ & $2.9 \mathrm{~m}$ & 70,000 & 2.3 \\
\hline Maine: & $\begin{array}{l}\text { Somewhat } \\
\text { Integrative }\end{array}$ & $1.3 \mathrm{~m}$ & 5,000 & .3 \\
\hline Michigan: & $\begin{array}{l}\text { Somewhat } \\
\text { Integrative }\end{array}$ & $10.0 \mathrm{~m}$ & 125,000 & 1.2 \\
\hline New Jersey: & $\begin{array}{l}\text { Somewhat } \\
\text { Integrative }\end{array}$ & $8.7 \mathrm{~m}$ & 350,000 & 4.0 \\
\hline Oregon: & $\begin{array}{l}\text { Somewhat } \\
\text { Integrative }\end{array}$ & $3.7 \mathrm{~m}$ & 125,000 & 3.4 \\
\hline Vermont: & $\begin{array}{l}\text { Somewhat } \\
\text { Integrative }\end{array}$ & 623,908 & 5,000 & .8 \\
\hline
\end{tabular}




\begin{tabular}{|c|c|c|c|c|}
\hline Texas: & $\begin{array}{l}\text { Somewhat } \\
\text { Integrative }\end{array}$ & $23.5 \mathrm{~m}$ & $1.4 \mathrm{~m}$ & 6.0 \\
\hline Colorado: & Mixed & $4.7 \mathrm{~m}$ & 225,000 & 4.7 \\
\hline Indiana: & Mixed & $6.3 \mathrm{~m}$ & 70,000 & 1.1 \\
\hline Kansas: & Mixed & $2.7 \mathrm{~m}$ & 70,000 & 2.5 \\
\hline Minnesota: & Mixed & $5.1 \mathrm{~m}$ & 70,000 & 1.3 \\
\hline Nebraska: & Mixed & $1.8 \mathrm{~m}$ & 27,500 & 1.6 \\
\hline North Carolina: & Mixed & $8.9 \mathrm{~m}$ & 300,000 & 3.4 \\
\hline Virginia: & Mixed & $7.6 \mathrm{~m}$ & 225,000 & 2.9 \\
\hline Arkansas: & $\begin{array}{c}\text { Somewhat } \\
\text { punitive }\end{array}$ & $2.8 \mathrm{~m}$ & 27,500 & 1.0 \\
\hline Idaho: & $\begin{array}{c}\text { Somewhat } \\
\text { punitive }\end{array}$ & $1.5 \mathrm{~m}$ & 27,000 & 1.9 \\
\hline Louisiana: & $\begin{array}{c}\text { Somewhat } \\
\text { punitive }\end{array}$ & $4.3 \mathrm{~m}$ & 27,500 & .6 \\
\hline Rhode Island: & $\begin{array}{c}\text { Somewhat } \\
\text { punitive }\end{array}$ & $1.0 \mathrm{ml}$ & 27,500 & 2.6 \\
\hline West Virginia: & $\begin{array}{c}\text { Somewhat } \\
\text { punitive }\end{array}$ & $1.8 \mathrm{~m}$ & 5,000 & .3 \\
\hline Wyoming: & $\begin{array}{c}\text { Somewhat } \\
\text { punitive }\end{array}$ & 515,094 & 5,000 & 1.0 \\
\hline Arizona: & Punitive & $6.1 \mathrm{~m}$ & 500,000 & 8.1 \\
\hline Georgia: & Punitive & $9.3 \mathrm{~m}$ & 225,000 & 2.4 \\
\hline Mississippi: & Punitive & $2.9 \mathrm{~m}$ & 27,500 & .9 \\
\hline Missouri: & Punitive & $5.8 \mathrm{~m}$ & 70,000 & 1.2 \\
\hline Oklahoma: & Punitive & $3.6 \mathrm{~m}$ & 70,000 & 2.0 \\
\hline South Carolina: & Punitive & $4.3 \mathrm{~m}$ & 27,500 & .6 \\
\hline Tennessee: & Punitive & $6.0 \mathrm{~m}$ & 125,000 & 2.0 \\
\hline Utah: & Punitive & $2.6 \mathrm{~m}$ & 70,000 & 2.7 \\
\hline
\end{tabular}

Source: The Anti-Immigrant Movement That Failed: Positive Integration Policies by State Governments Still Far Outweigh Punitive Policies Aimed at New Immigrants, PROGRESSIVE STATES NETWORK (Sept. 2008). http://www.progressivestates.org/files/reports/immigrationSept08.pdf.

It is difficult to see how Hispanic huddled masses, concentrations, or clusters can fully explain prevalent sentiments since, behind Arizona, all states with high undocumented immigrant populations belong to more lenient categories. As Table 3 shows, California has an undocumented immigrant population ratio of 6.6 percent but ranks in the "integrative" category; Texas, with 6.0 percent, in the "somewhat integrative"; Colorado, with 4.7 percent, in the "mixed"; District of Columbia, with 4.7 percent, in the "somewhat integrative"; and Florida, also with 4.7 percent, in the "inactive." What constitutes "punitive" actions or orientations must be sought in other explanations: 
race (as FAIR illustrates), politics (candidates as rational actors, that is, opportunists), or partisanship (ideological solidarity claims).

\section{Table 4: Undocumented Immigrants \& State Policy Trajectories}

\begin{tabular}{|c|c|c|c|}
\hline $\begin{array}{c}\text { Immigration } \\
\text { Policy Stands: }\end{array}$ & $\begin{array}{c}\text { Total } \\
\text { Population } \\
\text { (2005): }\end{array}$ & $\begin{array}{c}\text { Undocumented } \\
\text { Immigrant Population } \\
\mathbf{( 2 0 0 5 ) :}\end{array}$ & $\begin{array}{c}\text { Undocumented } \\
\text { Population as \% of } \\
\text { Total Population: }\end{array}$ \\
\hline Inactive: & $64.0 \mathrm{~m}$ & $1.5 \mathrm{~m}$ & 2.3 \\
\hline Integrative: & $88.9 \mathrm{~m}$ & $4.2 \mathrm{~m}$ & 4.7 \\
\hline Somewhat Integrative: & $56.3 \mathrm{~m}$ & $2.2 \mathrm{~m}$ & 3.9 \\
\hline Mixed: & $37.3 \mathrm{~m}$ & $1.0 \mathrm{~m}$ & 2.6 \\
\hline Somewhat Punitive: & $12.0 \mathrm{~m}$ & $.1 \mathrm{~m}$ & .8 \\
\hline Punitive: & $40.8 \mathrm{~m}$ & $1.1 \mathrm{~m}$ & 2.7 \\
\hline
\end{tabular}

Source: The Anti-Immigrant Movement That Failed: Positive Integration Policies by State Governments Still Far Outweigh Punitive Policies Aimed at New Immigrants, PROGRESSIVE STATES NETWORK (Sept. 2008). http://www.progressivestates.org/files/reports/immigrationSept08.pdf.

Though the anti-immigration movement was brewing independent of Barack Obama's political rise, Obama's presidency provided a wonderful opportunity to make those sentiments pivotal. The federal government's historically slow responses to illegal immigrants feed into opponents of big government and states facing fiscal concerns, and with Republicans reclaiming anti-immigration positions (from the Democrats, as evident with the 1993 NAFTA vote), Obama and the Democrats face a double jeopardy in the 2012 election.

\section{Constitutional Conundrum}

That immigration is not mentioned in the U.S. Constitution does not mean it is conceptually absent; it is an implied power of any sovereign country, inherent in the federal/central government, and the Article 1 , Section 8 authority to oversee the naturalization process. ${ }^{76} \mathrm{Nev}-$ ertheless, illegal immigration in the United States generates tension between the federal and state/local governments: formulating immigration policy belongs in the federal domain, but state and local governments pick up the costs of illegal immigrants (from mostly freeriding various services and not paying taxes). ${ }^{77}$ How the two can rec-

75 For Obama and Democrats, Immigration Overhaul a Political No-Brainer, NAT'L PUB. RADIO (May 10, 2011), http://www.npr.org/blogs/itsallpolitics/2011/05/10/136169440/for-obamaand-democrats-immigration-overhaul-a-political-no-brainer.

76 Things That Are Not in the U.S. Constitution, U.S. CONST. OnLINE, http://www.usconstitution.net/constnot.html (last visited Mar. 2, 2012).

77 The Impact of Unauthorized Immigrants on the Budgets of State and Local Government, CONG. BUdGET OFF. (Dec. 6, 2007), available at http://www.cbo.gov/publication/41645. 
oncile may ultimately depend on public attitudes, swayed as they are between the negotiable and the non-negotiable poles by both personal persuasion (for example, legislative compromises) and secular circumstances (for example, possible recession).

Extant anti-immigration sentiments feed into this tension, converting positions over a specific issue (immigration) into a broadbased argument against "big" government or "governmental interference." 78 In a growing number of states, fearing the unnecessary costs of being challenged by the federal government, groups have increasingly supported stronger federal powers to control illegal immigration. A bipartisan group called "Utah compact" exposes sentiment control: it involves the church's goal of spreading "the word" (whatever that word may be), thus necessitating broader public acceptance, and businesses, which have always been supportive of low-wage workers. ${ }^{80} \quad$ That the Republican Party attracts precisely both these groups paves the way for compromises (without quelling the original antiimmigration sentiment). It is a worthwhile stock-taking feature for any immigration-policy reformer.

\section{SB1070 Costs:The BIG PICTURE AND THE DETAILS}

The two types of costs discussed below include the immediate economic impact on Arizona from SB1070 and the legislative costs from similar legislations before SB1070. ${ }^{81}$ Such a backdrop exposes yet another type of cost (of ignoring lessons): the value-interest tradeoff impacting the electoral calendar.

\section{A. Economic Costs: Recession}

Arizona apparently passed SB1070 in the wake of its $\$ 4.5$ billion deficit: $^{82} 80$ percent of the budget for state parks was cut, while 300,000

78 Mark Willen, The Silly Debate Over Big Government: Sloganeering Only Obscures the Debate Over the Proper Role of Government, THE KIPLINGER LETTER (Mar. 10, 2010), http://www.Kiplinger.com/columns/washington/archives/the-silly-debate-over-biggovernment.html.

79 David Stoll, In Focus: The Immigration Debate (Martha Honey \& Tom Barry, eds., 1997), available

at

http://www.johnpauliihs.org/johnpaul/community/pattiweinbrenner/files/2011/11/Print-In-

Focus_-The-Immigration-Debate.pdf.

80 See Republican Extremists Push Utah Towards Anti-Immigrant Legislation, supra note 24.

81 Valeria Fernández, How Much do Anti-immigration Bills Really Cost?, CAL. Progress REP. (Jan. 26, 2011), http://www.californiaprogressreport.com/site/how-much-do-antiimmigration-bills-really-cost.

82 American Immigration Council, How Much will Arizona's Immigration Bill (SB1070) Cost? (Apr. 21, 2010), http://www.americanimmigrationcouncil.org/newsroom/release/how-muchwill-arizonas-immigration-bill-sb1070-cost; How Much is Arizona's Immigration Law SB1070 
adults and 39,000 children were dropped from the state's healthcare programs. ${ }^{83}$ Since 2006 , the recession pushed 61.5 percent of all state mortgage-holders under water, while 50 percent of all jobs in the construction industry vanished. ${ }^{84}$ Arizona is among the five states with the highest foreclosure rates today, while evaporating jobs and mounting unemployment continued to plague Arizona even in August 2010. ${ }^{85} \mathrm{~A}$ University of Arizona study suggested SB1070 would threaten the $\$ 44$ billion generated by immigrant workers, ${ }^{86}$ as well as the 400,000 fulltime jobs this entailed, not to mention the 35,000 Latin-owned businesses (with 2002 sales worth $\$ 4.3$ billion and 39,363 jobs), and Mexican visitors and shoppers. ${ }^{87}$ Table 5 profiles Arizona's SB1070 background and subsequent costs.

Costing Arizona?, ARIZ. IMMIGR. L. TEXT (July 12, 2011), http://www.arizona-immigration-lawtext.com/how-much-is-arizonas-immigration-law-sb1070-costing-arizona.html.

83 Arizona State Budget Cuts Will Likely Force State Park Closures, ENV'T AM. (Apr. 8, 2011), http://www.environmentamerica.org/news/ame/arizona-state-budget-cuts-will-likely-forcestate-park-closures; How Much will Arizona's Immigration Bill (SB1070) Cost?, supra note 82; Alia Beard Rau, Needy Arizona Children to Lose Health Care, Medicine Coverage, THE NEW ARIZ. REPUBLIC

(Mar. 20 ,

2010),

http://www.azcentral.com/news/articles/2010/03/20/20100320arizona-kids-lose-health-

coverage.html; Kevin Sack, Arizona Drops Children's Health Program, N.Y. TIMES (Mar. 18, 2010), http://www.nytimes.com/2010/03/19/health/policy/19arizona.html; Neala Schwartzberg, Budget Cuts Close More Than Half Arizona State Parks for 2010, EXAMINER (Feb. 13, 2010), http://www.examiner.com/offbeat-places-in-national/budget-cuts-close-more-than-half-arizonastate-parks-for-2010.

84 Ken Silverstein, Tea Party in Sonora: For the Future of G.O.P. Governance, Look to Arizona, HARPER's MAG. (July 2010), http://harpers.org/archive/2010/07/0083023.

85 Unemployment Rate Rises in 27 States in August, USA TODAY (Sept. 21, 2010), http://www.usatoday.com/money/economy/2010-09-21-unemployment-rate-state_N.htm.

86 This was at the Udall Center for Studies of Public Policy.

87 Tim Gaynor, Arizona Border Businesses Lose Key Mexican Clients, REUTERs (May 23, 2010), http://www.reuters.com/article/2010/05/23/immigration-usa-tradeidUSN2117927220100523. 
Table 5: Arizona's Costs on Eve of SB1070 \& After

\begin{tabular}{|c|c|}
\hline Timeframe: & Costs: \\
\hline *On eve of SB1070: & $\begin{array}{l}\text { * } \$ 4.5 \text { billion budget deficit: } 80 \text { percent funds for state parks } \\
\text { cut; } 300,000 \text { adults and } 47,000 \text { children dropped from } \\
\text { healthcare programs } \\
\text { * Recession pushed } 61.5 \text { percent mortgage-holders under } \\
\text { water since } 2006 \\
* 50 \text { percent of all construction jobs vanished } \\
\text { *Illegal immigrants expanded faster than anywhere else in } \\
\text { the USA: from } 335,000 \text { in } 2000 \text { to } 560,000 \text { in } 2008 \\
\text { *Undocumented immigrants responsible for: } 12 \text { percent of } \\
\text { all workers, } 20 \text { percent of those in poverty, } 33 \text { percent of } \\
\text { people without health insurance, and } 16 \text { percent of school } \\
\text { population }\end{array}$ \\
\hline $\begin{array}{c}\text { *Immediately after } \\
\text { SB1070: }\end{array}$ & $\begin{array}{l}\text { *2012 Republican National Party convention site shifted to } \\
\text { Tampa, Florida from Phoenix } \\
\text { * Pressure to shift } 2011 \text { Major League Baseball's All-Star } \\
\text { game from Phoenix } \\
\text { *Hotel cancellations so far: } \$ 6 \text { to } \$ 10 \text { million; over five } \\
\text { years: } \$ 90 \text { million } \\
\text { *Expected losses in “Tax revenues, wages and visitor } \\
\text { expenditures”: } \\
\$ 250 \text { million } \\
\text { *SB1070 threatens the USA } \$ 44 \text { billion of generated } \\
\text { immigrant worker income, } 400,000 \text { full-time jobs, } 35,000 \\
\text { Latin-owned business } \\
\text { (and } 39,363 \text { jobs) } \\
\text { *Boycott of Arizona by Mexico's } 6 \text { border states } \\
\text { *Travel advisory placed upon Arizona by Mexican } \\
\text { president }\end{array}$ \\
\hline
\end{tabular}

The Republican Party's 2012 convention was shifted to Tampa, Florida, from Phoenix, Arizona, under pressure, while the July 12, 2011, Major League Baseball's All-Star game was under similar pressure to shift venue. ${ }^{88}$ Hotel cancellations have thus far meant losses of

$\begin{array}{lcrrr}\text { Vote } & \text { WASH. } & \text { POST } & \text { (May } & 12,\end{array}$ 2010),

Krissah Thompson, Arizon just Arizona, but Texas also faces a similar problem. See Anti-immigrant Legislation Could Cause Texas Millions in Lost Mexican Investors, HisPaniCALly SPEAKING NeWs (Jan. 7, 2011), http://www.hispanicallyspeakingnews.com/notitas-de-noticias/details/anti-immigrationlegislation-could-cause-texas-millions-in-lost-mexica/4096/. 
between $\$ 6$ and $\$ 10$ million but over five years could be $\$ 90$ million with slightly more than one-third of the $\$ 250$ million losses expected in "tax revenue, wages and visitor expenditures". 89

The number of Arizona's illegal immigrants expanded faster than elsewhere in the United States, from 335,000 in 2000 to 560,000 in 2008 before the recession struck, so that by 2011, only 283,000 entered the state. ${ }^{90}$ Although there were no "beheadings" in Arizona, as Governor Brewer fancifully claimed, ${ }^{91}$ the Mexican president's drug war since December 2006, which uncovers beheaded bodies periodically, pushes traffickers north of the border, and feeds a recession-driven Arizona perception that undocumented immigrants are complicit.

Impressions drawn from these statistics were deep-rooted and widespread across Arizona. Whether rain (recession) or shine (prosperity), Celeste González de Bustamante (a third-generation American) of the University of Arizona's School of Journalism, posits that the "silent invasion" perception is old, constant, and inaccurate." Much like the Minutemen do today, she points out how a former $\mathrm{Ku}$ Klux Klan Grand Wizard, David Duke, set up shop in Douglas in 1977 to detain illegal aliens; that journalists, who rely almost exclusively on governmental sources for information, publicize the actions of illegal aliens over the silent but more positive and productive contribution of legal aliens; and that, ultimately, from all the television reports available, the public erroneously equates undocumented immigrants as "job stealers," "criminals," and "drug smugglers." SB1070 not only feeds this constituency but also alienates many legal aliens from voting -- two possible factors behind its 71 percent approval rating, mak-

89 Loís Romano, States Inspired by Arizona's Illegal-immigration Law Face Tough Fiscal Realities, WASH. POST (Jan. 29, 2011), http://washingtonpost.com/wpdyn/content/article/2011/01/28/AR2011012804042.html?referrer=emailarticle.

90 Estimated Number of Illegal Immigrants (most recent) by State, STATEMASTER (2011), http://www.statemaster.com/graph/peo_est_num_of_ill_imm-people-estimated-number-illegalimmigrants.

91 Andy Barr, Brewer's Beheading Claim Questioned, PoLITICO (June 30, 2010), http://www.politico.com/news/stories/0610/39240.html. 3.

92 Napolitano Decries the Rise in Violence, DAILY NEWS (Mexico City), Sept. 23, 2010, at

93 Kevin Spak, Blame Mexico's Calderon for Arizona's Law, Newser (May 12, 2010), http://www.newser.com/story/88519/blame-mexicos-calderon-for-arizonas-law.html.

94 Celeste Gonzalez de Bustamante, How did Arizona Become the $\square$ Show Me Your Papers State'? History and Media Provide Some Clues, BARriozonA (May 16, 2010), http://www.barriozona.com/SB1070_arizona_show_me_your_papers_state_celeste_gonzalez_bus tamantehtml.

95 Celeste González de Bustamante, Public Needs to Know Fall From Fiction About Undocumented Migrants, ARIZ. DAILY STAR (June 3, 2010), http://azstarnet.com/news/opinion/article_368f7d45-450d-5942-901c-04295f426542.html. 
ing Arizona, not the "Grand Canyon state," papers state." ${ }^{, 97}$

One routinely would expect the majority of any stable population to oppose illegal immigration (under dire economic conditions, even legal immigrants face more social alienation), especially as it becomes an unending stream. Yet, the 71 percent statistic exposes a vicious cycle: systematic efforts to "limit the already narrow ability of immigrants" to find a job, access public services, and obtain a driver's license, driving them into irregular behavior, culminating in arrest (for not having identification papers). ${ }^{98}$ Demographic factors compound this, as explained below.

According to the 2010 Census, Hispanics accounted for 78 percent of the U.S. population growth during the prior decade (the number of Caucasian children fell by 4.34 million during that time, the number of Hispanic children increased by 4.8 million). ${ }^{99}$ Caucasian children under-eighteen account for 41.6 percent in that age group against the 43.2 percent for Hispanics, ${ }^{100}$ making Caucasians a minority in ten U.S. states (Arizona, California, Florida, Georgia, Hawaii, Maryland, Mississippi, Nevada, New Mexico, and Texas) and thirty-five large cities (such as Atlanta, Georgia; Dallas, Texas; Orlando, Florida; and Phoenix, Arizona). ${ }^{101}$ Further, with a 24.6 percent population growth during the decade, the same census indicates Arizona will get one more seat in the U.S. House of Representatives. ${ }^{102}$ Of the eight representatives today, five are Caucasian Republicans, two are Hispanic Democrats, and one Caucasian Democrat (with both senators being Caucasian), making Arizona "ground zero" not just for antiimmigration legislations (SB1070) but also demographic changes negatively impacting Caucasians against Hispanics. Topping these statistics, the Caucasian median age of forty-one soars sky-high over the Hispanic's twenty-seven, and while 20 percent of U.S. Caucasians fall under eighteen-years of age, for Hispanics, this is 33 percent. Cau-

\footnotetext{
96 See Spak, supra note 93.

97 Id.

98 Eduardo Barraza, Judge Weakens SB 1070, Puts on Hold Law's Punching Effects, BARRIOZONA (July 28 , 2010), http://www.barriozona.com/SB1070_arizona_judge_susan_bolton_halts_law_provisions.html.

99 Hispanics Contribute 78\% of the Population Growth in the U.S., DAILY NEws (Mexico City), Apr. 8, 2011, at 5; Hope Yen, Hispanics Reach 50 Million Mark: U.S.: Minorities Yield 90\% of the Population Growth, DAILY News (Mexico City), Mar. 28, 2011, at 4.

100 Michael White, In Immigration Debate, Arizona is Ground Zero: Census: Generation Changes Makes State $\square$ test-case’, DAILY News (Mexico City), Mar. 24, 2011, at 4.

101 Barraza, supra note 98.

102 Maile L. Nadelhoffer \& Marshall J. Vest, Arizona Now the $16^{\text {th }}$ Most Populous State, U. ARIZ., Eller C. MGMT. (Dec. 23, http://ebr.eller.arizona.edu/research/articles/2010/Arizona_now_16th_most_populous_state.asp.
} 
casian fear is understandably sky-high, particularly in these states (though, like New Mexico, not every state has responded punitively). ${ }^{103}$

SB1070 nevertheless exposed some festering problems: 12 percent of all workers, 20 percent of those in poverty, 33 percent of people without health insurance, and sixteen percent of the school population, were illegal. ${ }^{104}$ Drubbing those perceptions, an April 29, 2010 Pew Research Center survey revealed Hispanics faced more discrimination than any other U.S. group: $:^{105} 23$ percent, as opposed to 18 percent for African-Americans, 10 percent for Caucasians, and 8 percent for Asians. Further, this anti-Hispanic discrimination was greater in 2009 than in 2001: 23 percent versus 19 percent (with 25 percent for African-Americans, 9 percent for Caucasians, and 8 percent for Asians in 2001).

\section{B. Legislative Costs}

Table 6 suggests that the costs of challenging anti-immigration bills may drive them out of the market. Hazelton, Pennsylvania, illustrates the emerging dilemma; it spent over $\$ 5$ million, almost half for legal fees, in an unsuccessful pursuit, ${ }^{106}$ but must now raise local taxes to pay that amount. ${ }^{107}$ This problem is not only haunting Governor Brewer in Arizona with SB1070 but also all other champions of antiimmigration bills. ${ }^{108}$

103 Wessler, supra note 28.

104 Steven A. Camarota, Center for Immigration Studies on the New Arizona Immigration Law, SB1070, CENTER IMMIGR. STUD. (Apr. 29, 2010), http://www.cis.org/announcement/AZimmigration-SB1070; Steven A. Camarota, Immigrants at Mid-Decade: A Snapshot of America's Foreign-Born Population in 2005, CENTER IMMIGR. STUD. (Dec. 2005), http://www.cis.org/ForeignBornPopulation2005

105 Hispanics and Arizona's New Immigration Law, PEW RES. CENTER (Apr. 29, 2010), http://pewresearch.org/pubs/1579/arizona-immigration-law-fact-sheet-hispanic-populationopinion-discrimination.

106 Immigration Ordinance Fact Sheet, FrEEMONT TRIBUNE (June 2, 2010), http://fremonttribune.com/article_1d702148-6f1d-11df-9211-001cc4c002e0.html.

107 Kevin O'Neil, Hazleton and Beyond: Why Communities Try to Restrict Immigration, MigRATION INFO. SOURCE (Nov.

http://www.migrationinformation.org/Feature/display.cfm?ID=805.

108 Id. 
Table 6: Anti-immigration Legislations \& Costs

\begin{tabular}{|c|c|}
\hline Cases: & Costs: \\
\hline $\begin{array}{l}\text { 1. Hazelton, Pennsylvania: } \\
\text { July } 13,2006\end{array}$ & $\begin{array}{c}\text { * } \$ 2.8 \mathrm{~m} \text { by October } 2010: \$ 400,000 \text { to } \\
\text { defending lawyers, like Kobach } \\
\text { *court-ordered } \$ 2.4 \mathrm{~m} \text { to plaintiffs' } \\
\text { lawyers } \\
\text { (under appeal): } \\
\text { *From Hazelton's Standard Speaker, } \\
\text { October } 10,2010 .\end{array}$ \\
\hline $\begin{array}{c}\text { 2. } \quad \text { Valley Park Missouri: } \\
\text { July } 17,2006\end{array}$ & $\begin{array}{c}* 270,000 \text { by July } 2009 \\
\text { *From New York Times, July 21, } 2009 .\end{array}$ \\
\hline $\begin{array}{l}\text { 3. Farmers Branch, Texas: } \\
\text { November 13, } 2006\end{array}$ & $\begin{array}{l}\text { *\$3.7m by January 2011-02-15 } \\
\text { *From: Dallas Morning News, } \\
\text { January 5, } 2011\end{array}$ \\
\hline $\begin{array}{l}\text { Fremont, Nebraska: } \\
\text { July 29, } 2008 \\
\end{array}$ & $* \$ 750,000$ by August 2010 \\
\hline $\begin{array}{l}\text { 5. SB1070, Arizona: } \\
\text { April 23, } 2010\end{array}$ & *\$1m by July 2010 \\
\hline
\end{tabular}

The key point should not be missed: anti-immigration sentiments are legitimate in any society with pragmatic leadership, but to connect them with race, politics, and partisanship becomes a recipe for disaster -- politically, socially, legally, and fiscally. It is also a lesson of history that the thickness of anti-immigration sentiments completely obscures. $^{109}$

\section{Values Versus Interests}

More than a generation ago, Edward Tufte's Political Control of the Economy alerted us to how the party in power, by manipulating transfer payments before elections, could in fact shift voter preferences. ${ }^{110}$ Since then, we have noticed how parties have shifted from their expected policy preferences. In spite of the Republican commitment to a balanced budget, Ronald Reagan and George W. Bush left a huge deficit, while Bill Clinton's unusual balanced-budget approach defied the typical Democrat expectation of utilizing public

\footnotetext{
109 Tim Kane \& Kirk Johnson, The Real Problem with Immigration . . . and the Real Solution, HERITAGE BACKGROUNDER (Mar. 2006), http://www.heritage.org/research/reports/2006/03/the-real-problem-with-immigration-and-thereal-solution.

110 EdWARd R. Tufte, Political CONTROL of THE ECONOMY (1978).
} 
money stimulation. ${ }^{111}$ Whether the atrophying voter interest in party preferences can be reduced to just this one pocket-book cause or not, voters alienated by shifts in their pet preferences seem to be substituting their interests with values. The rise of the Tea Party symbolizes, rather than actualizes, that. Thomas L. Friedman notes this as an "amorphous, self-generated protest," which he calls the "Tea Kettle movement" rather than the Tea Party: any Tea Party that says the simple answer is just shrinking government and slashing taxes might be able to tip the midterm elections in its direction, but cannot tip America in the right direction. There is a Tea Party for that, but it's still waiting for a leader. ${ }^{112}$

Symptoms may also be found in SB1070. Whereas SB1070 represents a Republican initiative, we also notice how, since not all Republicans interpret SB1070, uniformly, ${ }^{113}$ a platform radicalization may be in the offing. ${ }^{114}$ Pushing this point further, mid-term elections radicalize the anti-immigrant platforms. California's Proposition 187 was a case in point in 1994, SB1070 another in 2010. Senator John McCain, for example, once the bipartisan champion of immigration reform legislation (together with the late Senator Edward Kennedy) not only supported SB1070 but also assailed Judge Bolton's injunction. ${ }^{11}$

Broader still, deprived of their preferred party not upholding their pet interests, voters turn to values as their last stand against challenges of all sorts. By drifting more towards extreme positions than to the middle, voters also turn policymakers away from compromises and towards manichean positions. ${ }^{116}$ Regardless of how the SB1070 movement turns out, the "silent invasion" perception is likely to not only continue but also set the standards of elections -- if present electoral winds serve as a guide. After all, interests are negotiable, values not.

\section{CONCLUSIONS}

By unleashing a war between two silent forces -- the "silent invasion" perception and the silent legal immigrant majority -- SB1070

111 Steve Schifferes, Bill Clinton's Control of the Economy, BBC NEws (Jan. 15, 2001), http://news.bbc.co.uk/2/hi/business/1110165.stm.

112 Thomas L. Friedman, Tea Kettle Movement, N.Y. TIMES, Sept. 30, 2010, at A31

113 Or generally, anti-immigration measures.

114 Amy Walter, Election Night Results Foreshadow Competitive 2012, ABC NEWs (Nov. 9 , 2011), http://abcnews.go.com/blogs/politics/2011/11/election-night-results-foreshadowcompetitive-2012/.

115 Devin Dwyer, John McCain Attacks Janet Napolitano Over Immigrant $\square$ Spotters' in Arizona, ABC NEWs (May 4, 2011), http://abcnews.go.com/blogs/politics/2011/05/john-mccainattacks-janet-napolitano-over-immigrant-spotters-in-arizona/.

116 Edward L. Glaeser et al., Strategic Extremism: Why Republicans and Democrats Divide on Religious Values, 120 Q. J. ECON. 1283 (2005). 
may be popularizing the emergent value-based recalculation of politics, shifting from the traditional electoral platforms based on interest. ${ }^{117}$ Immigration might have catalyzed this movement in 2010, but what remains in store can only be conjectured with concern. In the wings, a vast array of other issues awaits a similar recalculation: government intervention, trade based on reciprocation, President Barack Obama's "change we can believe in," deploying more troops to Afghanistan against a fixed time-table to withdraw completely, and so forth. ${ }^{118}$ Whereas the Bush administration is just as culpable as the Obama administration over the first two issues, the last two serve as a Republican whip against the Democratic Party on all four, indicating how interest-based calculations can be twisted enough to serve valuebased counterparts. ${ }^{119}$

SB1070 was not the first state legislation to shake mid-term elections, but the 2010 political landscape gives it distinctiveness: the ageold argument equating liberal-minded Democrats to fiscal recklessness can not only thicken but also produce a new political plot given that Obama is a different kind of American to enter the White House. ${ }^{120}$ Finally, the outpouring of anti-immigration sentiment against the Democrats creates a stew almost anyone in a recession would taste: the Republican taste is supplemented by more appeals to values than interests (while the Democrats' taste is the opposite), thus reinforcing the double Democratic jeopardy. The it's the economy, stupid cliché might be spawning an it's the politics, stupid successor now that the economy has been rendered so helpless."

Buried in the process might be some enduring edifices built upon social capital and business enterprise -- in local, national, and international communities. Whether values move in cycles or not, the lasting legacy of SB1070 could very well be unleashing so many values that, in

117 Tom Tancredo, Immigration, Citizenship and National Security: The Silent Invasion, 15 MEDITERRANEAN Q. 4 (2004), available at: http://www.dankopelman.com/rmf/the_silent_invasion.htm.

118 Stephen Walt, Coming Up Empty, FOREIGN POL'Y (Oct. 25, 2011), http://www.foreignpolicy.com/articles/2011/10/25/obama_foreign_policy_coming_up_empty?page $=$ ful.

119 Jo Freeman, The Political Culture of the Democratic and Republican Parties, 101 PoL. SCI. Q. 327 (1986); Michael Medved, The Party of Interests Versus the Party of Values, TOWNHALL.COM (Nov. 4, 2008), http://townhall.com/columnists/michaelmedved/2008/11/04/the_party_of_interests_versus_the_p arty_of_values/page/full/.

120 Jonathan Freedland, Intellectual, Tolerant and Focused: A Very Different President, THE GUARDIAN (Nov. 5, 2008), http://www.guardian.co.uk/world/2008/nov/06/barack-obamajohnmccain.

121 Thomas Tuma, It's the Politics, Stupid: Don't Just Bash the Bankers, SPIEGEL OnLINE INT'L (Oct. 26, 2011), http://www.spiegel.de/international/europe/0,1518,794084,00.html. 
one form or another, the longer they linger, the more disruptive politics-as-usual might become.

\section{IMPLICATIONS}

Such a values-versus-interests setting carries profound implications. Socially, it sharpens divisions between in-groups and out-groups in spite of the significant convergences recorded after World War I. ${ }^{122}$ Politically, it revives the manichean outlook of both the Cold War ("better dead than red," (the "with-us or against-us" ${ }^{\text {"124 }}$ slogan) in a domestic context, and with it, inefficient groupings, exorbitant expenditures, and unnecessary divisions. Economically, it resuscitates the villains behind the "great recession," such as financial corporations, rather than revitalize the victims, such as the day laborer. Legally, it exposes how a sparse constitution faces more pressures under the increasing complexities of modernization than in the society of the Founding Fathers -- particularly widening the original state-federal governmental gaps to monstrous levels today. ${ }^{125}$ Psychologically, it raises the apprehension ante in every group (the in-group owing to the "silent invasion" fear, which must be sustained whether it is receding or not, and the out-group from not wanting to get dragged into the play), thus diverting more attention and resources away from productive pursuits. Time unnecessarily could be lost in figuring out how the next-door neighbor has shifted his/her views given the cataclysmic changes afoot. If there is a time to talk in order to bridge irreconcilable differences, the present moment imposes itself with utmost urgency.

122 For example, adult males extending voting rights to women or civil rights to AfroAmericans; or democracy awakening indigenous groups or other minorities in other parts of the world. For immigration application, see Tiane L. Lee and Susan T. Fiske, Not an Outgroup, Not Yet an Ingroup: Immigrants in the Stereotype Content Model, INT'L J. INTERCULTURAL REL. 30, 751-68 (2006).

123 EDMUND Lindop \& SARAH DECAPUA, AMERICA IN THE 1950s (2010).

124 With Us or Against Us: Studies in Global Anti-Americanism (Tony Judt \& Denis Lacorne eds., 2005).

125 See also Neal McCluskey, K12 Education Subsidies, CATO InsT. (May 2009), http://www.downsizinggovernment.org/k-12-education-subsidies\#Waste; Becca Miller et al., The State of Public Health Preparedness, KAISER FAMILY FOUnd. (Mar. 2008), http://www.kaiseredu.org/Issue-Modules/The-State-of-Public-Health-Preparedness/BackgroundBrief.aspx; Jeremy Redmon \& David Wickert, State Immigration Law Beset With Gaps, Confusion, ATLANTA J. CONST. (Nov. 8, 2011), http://www.ajc.com/news/georgia-politics-elections/stateimmigration-law-beset-1219875.html; Joe Weisenthal \& Gus Lubin, There's One Huge State Budget Crisis that Everyone is Refusing to Talk About, BUS. INSIDER (Jan. 3, 2011), http://www.businessinsider.com/texas-state-budget-crisis-2001-1. 
Appendix 1: State-wise Breakdown of Immigration Positions by State

\begin{tabular}{|c|c|c|}
\hline States: & Legislative Actions: & Miscellaneous: \\
\hline Alabama: & $\begin{array}{l}\text { *Robert Bently (R) proposes “unwelcoming } \\
\text { environment" } \\
\text { *SB1070 copycat signed by Governor Robert } \\
\text { Bentley, with E-verify provision, } \\
\text { in June } 2011 \\
\end{array}$ & $\begin{array}{c}\text { *Challenged by } \\
\text { ACLU, SPLC, } \\
\text { National } \\
\text { Immigration Law } \\
\text { Center, Asian } \\
\text { Justice Coalition }\end{array}$ \\
\hline Arizona: & $\begin{array}{l}\text { *HB2281 seeks to prohibit certain courses: } \\
\text { "not include . . . any courses or classes ... } \\
\text { designed . . . for pupils of a particular ethnic } \\
\text { group; advocate ethnic solidarity ..." }\end{array}$ & \\
\hline \multicolumn{3}{|l|}{ Arkansas: } \\
\hline California: & $\begin{array}{l}\text { *Michael Erickson (R) proposes Support } \\
\text { Federal Immigration Law Act } \\
\text { *State Secretary Debra Brown proposes } \\
\text { copycat SB1070 } \\
\end{array}$ & \\
\hline Colorado: & $\begin{array}{l}\text { *Dan Maes }(\mathrm{R}) \text { proposes E-Verify: stop } \\
\text { transfer of funds from Colorado }\end{array}$ & \\
\hline Florida: & $\begin{array}{l}\text { *Attorney General Rick Scott (R) and Bill } \\
\text { McCollum (D): bipartisan opposition to anti- } \\
\text { immigration laws } \\
\text { *Somos Republicans also refute such laws } \\
\text { *William Snyder (R) proposes such a bill }\end{array}$ & $\begin{array}{l}\text { *Former Governol } \\
\text { Jeb Bush against } \\
\text { such a bill }\end{array}$ \\
\hline
\end{tabular}




\begin{tabular}{|c|c|c|}
\hline Georgia: & $\begin{array}{l}\text { *Governor Nathan Deal (R) signed SB1070 } \\
\text { type of law which was blocked by Judge } \\
\text { Thomas Thrash in June } 2011 \text { to prevent "a } \\
\text { climate of hostility, fear, mistrust and } \\
\text { insecurity that all illegal aliens will leave } \\
\text { Georgia." } \\
\text { *Seeks to ban undocumented immigrants } \\
\text { from attending all public universities } \\
\text { *HB978: seize cars driven by undocumented } \\
\text { immigrants who violate traffic laws } \\
\text { *HB971: driving with out-of-state license } \\
\text { made misdemeanor } \\
\text { *HB127: denies automatic citizenship to } \\
\text { children of undocumented immigrants } \\
\text { HB1028: imposes } 2 \% \text { tax on wire-transfers } \\
\text { *SB25: lies about renewing driver's license } \\
\text { made a felony } \\
\text { *SB335: prohibits state agencies from } \\
\text { preferring applicants using another language }\end{array}$ & $\begin{array}{c}\text { *Georgia Farm } \\
\text { Bureaus oppose } \\
\text { any anti- } \\
\text { immigration bills } \\
\text { *Challenged by } \\
\text { ACLU, SPLC, } \\
\text { National } \\
\text { Immigration Law } \\
\text { Center, Asian } \\
\text { Justice Coalition }\end{array}$ \\
\hline Illinois: & $\begin{array}{l}\text { *State Representative Bill Mitchell (R) and } \\
\text { Decatur's Adam Brown: }\end{array}$ & \\
\hline Indiana: & $\begin{array}{l}\text { *Senator Mike Delph (R) sought employer } \\
\text { sanctions (SB335) in } 2003 \\
\text { *He also led the anti-immigration legislations } \\
\text { in May 2010, due to go into effect on July1, } \\
\text { but halted by District } \\
\text { Judge Sarah Evans Barker }\end{array}$ & $\begin{array}{c}\text { *Legislative } \\
\text { deadlock: } \\
\text { Republicans } \\
\text { control one house, } \\
\text { Democrats the } \\
\text { other } \\
\text { * Governor Mitch } \\
\text { Daniels (R) is } \\
\text { neutral }\end{array}$ \\
\hline Iowa: & $\begin{array}{c}\text { *Former Governor Terry Branstad calls for } \\
\text { denying education to children of } \\
\text { undocumented immigrants }\end{array}$ & \\
\hline Kentucky: & $\begin{array}{c}\text { *State Senator David Williams proposes } \\
\text { copycat SB1070 bill in January } 2011\end{array}$ & \\
\hline Louisiana: & & $\begin{array}{l}\text { *Has only } 25,000 \\
\text { undocumented } \\
\text { immigrations }\end{array}$ \\
\hline Maryland: & $\begin{array}{c}\text { *Favors any legislation premised upon } \\
\text { undocumented immigrant ultimately } \\
\text { becoming citizen } \\
\text { *15 anti-immigration bills pending (all by one } \\
\text { legislator: Pat McDonough }=\mathrm{R} \text { ) }\end{array}$ & $\begin{array}{l}\text { *February } 17,2011 \text { : } \\
\text { Offers in-state } \\
\text { tuition break for } \\
\text { undocumented } \\
\text { immigrants } \\
\end{array}$ \\
\hline
\end{tabular}




\begin{tabular}{|c|c|c|}
\hline Massachusetts: & $\begin{array}{c}\text { *Charles Baker }(\mathrm{R}) \text { and Timothy Cahill }(\mathrm{D}) \\
\text { seek "toughest-on-immigration" bill }\end{array}$ & \\
\hline Michigan: & $\begin{array}{l}\text { *Rep. Kim Meltzer (R): empower police to } \\
\text { arrest } \\
\text { *Governor candidate Michael Bouchard (R) } \\
\text { wants SB1070 }\end{array}$ & \\
\hline Minnesota: & *Expected in 2011 & $\begin{array}{l}\text { *Former Senator } \\
\text { Norm Coleman } \\
(\mathrm{R}) \text { proposes } \\
\text { reaching out to } \\
\text { Latinos }\end{array}$ \\
\hline Mississippi: & $\begin{array}{l}\text { *State Senator Joey Fillingane }(\mathrm{R}) \text { pushes } \\
\text { SB2179 (permits police to check immigration } \\
\text { status during traffic violation; employee } \\
\text { sanctions; crime to be without } \\
\text { immigration papers } \\
\text { *Opposed by Governor Haley Barbour } \\
\text { *Passed by both houses ( } 77-40 \text { in House); } \\
\text { kills SB2032 (Immigration Reform Act of } \\
\text { 2010) }\end{array}$ & $\begin{array}{l}\text { *Many Democrats } \\
\text { supported House } \\
\text { bill }\end{array}$ \\
\hline Nebraska: & $\begin{array}{l}\text { *Kris Kobach influences copycat SB1070 bill } \\
\text { (employees and landlords must verify } \\
\text { immigration status of workers and tenants) } \\
\text { *Mayor Donald B. Edwards resigns } \\
\text { December } 2010 \text { when Freemont citizens vote } \\
\text { through a referendum to support } \\
\text { anti-immigration actions }\end{array}$ & \\
\hline New Mexico & $\begin{array}{l}\text { Diane Denish (D) and Susana Martinez (R): } \\
\text { stop giving drivers license to } \\
\text { undocumented immigrants } \\
\text { *Former seeks to repeal } 2003 \text { law granting } \\
\text { licenses, while latter also asks for withholding } \\
\text { lottery scholarships }\end{array}$ & $\begin{array}{l}* \text { Democrat- } \\
\text { Republican } \\
\text { similarities }\end{array}$ \\
\hline North Carolina: & $\begin{array}{c}\text { State Representative George Cleveland (R) } \\
\text { proposes HB11 to ban undocumented } \\
\text { immigrants from public universities and } \\
\text { community colleges }\end{array}$ & \\
\hline Ohio: & *SB1070 copycat in Cincinnati & $\begin{array}{c}\text { *Opposed by } \\
\text { League of Latin } \\
\text { American Citizens } \\
\text { of Ohio }\end{array}$ \\
\hline
\end{tabular}




\begin{tabular}{|c|c|c|}
\hline Oklahoma: & $\begin{array}{l}\text { *2007 Oklahoma Taxpayer and Citizen } \\
\text { Protection Act: most severe anti-immigrant } \\
\text { legislation before SB1070: made it illegal to } \\
\text { transport undocumented immigrants, } \\
\text { employers were required to check papers } \\
\text { *Rep. Randy Terrill's Arizona Plus: seize } \\
\text { vehicles and property used to harbor or } \\
\text { transport undocumented immigrants }\end{array}$ & \\
\hline Pennsylvania: & $\begin{array}{l}\text { *Rep. Daryl Metcalfe }(\mathrm{R}) \text { challenges } 14^{\text {th }} \\
\text { Amendment: worried about anchor babies } \\
* 2006 \text { Hazelton bill struck down by federal } \\
\text { judge in July } 2007 \text {, then appeals struck down } \\
\text { by } 3^{\text {rd }} \text { U.S: Circuit Court of Appeals in } \\
\text { Philadelphia, September } 2010 \\
\end{array}$ & $\begin{array}{c}\text { *Metcalfe belongs } \\
\text { to SLLI; opposed } \\
\text { by ACLU }\end{array}$ \\
\hline South Carolina: & $\begin{array}{l}\text { *Former Governor Mark Sanford (R) claims } \\
2008 \text { anti-immigration bill the strictest in the } \\
\text { USA: employers required to check } \\
\text { immigration status; harboring and } \\
\text { transporting undocumented immigrants } \\
\text { became illegal } \\
\text { *State Senator Larry Martin behind } \\
\text { this as well } \\
\text { *Governor Nikki Haley signs SB1070-like bill } \\
\text { (S20) in June 2011, but adds E-verification, } \\
\text { and creates \$1.3 million Enforcement Unit to } \\
\text { connect local and federal authorities (January } \\
1,2012 \text { implementation }\end{array}$ & $\begin{array}{l}\text { *ACLU to file suit } \\
\text { *Mexican } \\
\text { consulate issues } \\
\text { warning to } \\
\text { Mexicans in South } \\
\text { Carolina }\end{array}$ \\
\hline Tennessee: & $\begin{array}{l}\text { *Governor Phil Bredesen seeks copycat } \\
\text { SB1070 bill }\end{array}$ & \\
\hline Texas: & $\begin{array}{c}\text { *State Representative Debbie Riddle (R) } \\
\text { seeks copycat SB1070; refutes argument } \\
\text { Houston is sanctuary city } \\
\text { *HB17 (Riddle): sees undocumented } \\
\text { immigration as criminal trespassing rather } \\
\text { than an administrative offense } \\
\text { *HB183 (Solomons): police to verify } \\
\text { immigration status of arrestees } \\
\text { *HB296 (Riddle): photo ID needed to vote } \\
\text { *HB22 (Riddle) schools to determine } \\
\text { immigration status } \\
\text { *HB38 (Berman): English as official language } \\
\text { *HB81 (Flynn): prohibits financing non- } \\
\text { English materials } \\
\text { *HB197 (Solomons): proof of citizenship }\end{array}$ & $\begin{array}{l}\text { *Texas Alliance, } \\
\text { Texas Associate of } \\
\text { Business, and Texas } \\
\text { Association of } \\
\text { Mexican-American } \\
\text { Chambers of } \\
\text { Commerce oppose } \\
\text { copying SB1070 } \\
\text { *Governor Rick } \\
\text { Perry (R) also in } \\
\text { opposition: says } \\
\text { state's motto is } \\
\text { "friendship" }\end{array}$ \\
\hline
\end{tabular}




\begin{tabular}{|c|c|c|}
\hline & $\begin{array}{c}\text { needed to work } \\
\text { *HB292 (Berman): denies birth certificate to } \\
\text { children of undocumented immigrants } \\
\text { *HB293 (Berman): denies children of } \\
\text { undocumented immigrants any benefits }\end{array}$ & \\
\hline Utah: & $\begin{array}{l}\text { *July } 2009 \text { law: employing undocumented } \\
\text { immigrants made illegal, argument pushed } \\
\text { further by Governor Gary R. Herbert (R) } \\
\text { *State Representative Stephen Sandstrom } \\
\text { (R) authors anti-immigrant bill influenced by } \\
\text { FAIR (through IRLI) } \\
\text { *List of undocumented immigrants } \\
\text { published July 2010: unpopular } \\
\text { *“Utah compact”: 5-pt proposal (immigration } \\
\text { as federal issue, immigrants } \\
\text { play important role) }\end{array}$ & $\begin{array}{c}\text { *Opposition voices } \\
\text { from business } \\
\text { groups, Mormons, } \\
\text { and law } \\
\text { enforcement } \\
\text { officials } \\
\text { *Salt Lake County } \\
\text { Council, } \\
\text { Sutherland } \\
\text { Institute, \& } \\
\text { Mormon Church } \\
\text { support } \\
\text { "Utah compact" }\end{array}$ \\
\hline Wisconsin: & $\begin{array}{l}* \text { Scott Walker }(\mathrm{R}) \text { shifts position to support } \\
\text { Arizona's SB1070 }\end{array}$ & \\
\hline
\end{tabular}

